\title{
Transport Corridors as a Social-Economic Energizer
}

\section{Besjana Qaja}

Faculty of Urban Planning and Environment Management (FUPEM), POLIS University Tirana, Albania

\section{Abstract}

Transport corridors and their socio-economic impact have been analyzed and explored in many cases. In the transport sector, there is a series of problems that affect the quality of life of the inhabitants in different regions. These issues need to be analysed and to find the cause and consequences that they cause and hinder the further development of the region initially and subsequently affect the national level. Moreover, roads as a construction structure have a very important role in the economic development of a country. They enable quick and convenient transportation of people to settlements as well as the economical transport of goods. The geographical position of the places, the natural beauties, and the sea are a prerequisite for tourism development. But in many cases, the natural and attractive attractions for tourists remain unused due to the lack of roads or the existence of a poor road network. The inspiration for the development of this topic comes from the daily observation of the transport situation and from receiving information through various publications such as studies, strategies or thematic books, discussions with colleagues and various events related to this sector. The research is focused on a specific case that can combine the theoretical part with the real situation to confront them both between using a specific methodology. The aim of this paper is to extract some of the reasons for regional development and energizing. As a case study is taken a part of route 7, in the Balkan peninsula which connects Albania with Kosovo and Serbia. Discussions on the construction of a highway between Albania and Kosovo are early, they were born on the eve of the First World War in Austria-Hungary. Even in the 1970s and 1980s, there was a discussion about building a road that would have to connect two locations. Based on this, it looks a good reason to search more and to analyse some effects of it in the social and economic life of citizens and residents of the impacted areas.

Keywords: transport corridors, socio impact, economic development, residents, transport situation.

\section{Introduction}

The purpose of this study thesis is realization of a good and focused study on the transport sector and regional development that it promotes in good planning cases related with transport corridors. In this regard, these transport corridors in their successful cases have acted as energizers for areas that were previously neglected by lack of infrastructure. After the creation of these interventions they have undergone a new development and are seen as an interactive part of these corridors. 
The relationship between transport and development is a subject of considerable theoretical interest and practical importance, and one that has occupied a good deal of attention over many years in both advanced and less-developed countries. Ideas about the nature of the relationship between transport and development have changed considerably over time. Of course, the basic importance of transport is not in question: transport is clearly a factor of fundamental importance in all economic activity, and the cost of transport one of the most significant variables in the market price of any commodity. (B. S. HOYLE 1973).

Transport has a major impact on the spatial and economic development of cities and regions. The attractiveness of particular locations depends in part on the relative accessibility, and this in turn depends on the quality and quantity of the transport infrastructure. In another scale of observing the state of things, cities are changing with the movement of people and businesses out from the center, increased suburbanization and the desire for lower residential and job densities. Suburbanization of employment has followed, and the simple local journey-to-work pattern or the public transport based movement to the strong central area employment location has been replaced by more complex longer distance car based movements.

At the regional scale, the links between transport and development are also evident. However, the links between transport and urban development is not well known, even in a physical sense. At the regional level, much infrastructure investment is justified on the basis of regional development benefits which accrue directly from improved accessibility. These benefits include a greater attractiveness for new firms who might move to the area, cheaper distribution of goods and a general expansion of the labour market areas (D. Banister, N. Lichfield 1995).

It is of conventional wisdom in development theories to consider inequalities as a structural factor of spatial accumulation (Dwyer, 1990). Transportation, among other factors, reinforces spatial inequality by linking a priori the most productive places. When a set of large cities are interacting at the regional level, they reinforce the regional spatial inequality of accessibility by their corridors of interaction; transportation corridors.

From an economic perspective, transportation corridors provide two fundamental attributes for territorial development: lower distribution costs and land supply for diverse activities. Since spatial accumulation tends to occur at productive places where there are adequate land supply and accessibility, corridors are in that context an efficient regional urbanization structure.

The emergence of transportation corridors, as a process, is the overlay in time and space of diverse transportation modes where they (the corridors) become the structure of urban regions. We can no longer speak of a set of interacting cities, but of a regional transactional space composed of diverse - more or less linked - specialized economic functions; a new spatial region (Jean-Paul Rodrigue 1996).

Looking back in time these aspects that are mentions by the authors are so well found and well implemented in different cases of corridors or old ancient roads all over the world. In a specific case that is take in consideration in this study is an old case as transport corridor in the ancient world near the Balkan is Egnatia road. The Via Egnatia was built by a Roman senator named Gnaeus Egnatius, who served as praetor with the powers of proconsul in the newly conquered province of Macedonia in the late 140s BCE. A milestone found near the place where the Via Egnatia crossed the Gallikos River, just west of Thessaloniki, is evidence for his activities. The 
bilingual inscription, now in the Archaeological Museum of Thessaloniki, correctly records a distance of 260 miles to Dyrrhachium (modern Durrës), the port on the Adriatic Sea where the road started. The road was very important. Connecting the eastern and western part of a once powerful state, the Macedonian kings had already built a road from the Adriatic to the Aegean Sea. For the Romans, it was essentially the continuation of the Via Appia: anyone coming from Rome and travelling to the east, would come to Brundisium, cross the Adriatic, reach Dyrrhachium (or Apollonia), and continue along the Via Egnatia (M. Fasolo 1976, F. O'Sullivan 1972).

Inspired by this the case study of The Road of Nation in Albania or Route 7 in Balkan peninsula which connect the port of Durres with Corridor X in Nish in Serbia, is taken in consideration for realization of this study one part of it. Otherwise called as Durres-Morine Corridor (Kukes) has a regional impact. It is likely to have more opportunities for transport links between the Adriatic Sea and the Mediterranean Sea provides Ports of Durres and Shengiin and has addressed in tire trade and the country of choice, to please Kosovo, Montenegro, Serbia, North Macedonia, and other Balkan countries such as Romania, Bulgaria and beyond.

In the main regional network, it is considered as the most optimal connection of the PanEuropean Corridor VIII to X on the Durres-Kukes-Pristine- Nish route. The construction of this Corridor is of particular importance due to the fact that freight and passenger transport occupies the major share of transport both domestically and with Kosovo. Important road segments, integral parts of the East-West, North-South, Durres-Morine corridors, tourist roads and those leading to the border crossings, have been constructed and put into use. Damaging factors are the illegal constructions along the main roads that still prevail, mainly due to the lack of second level infrastructure and access roads.

\section{Material and Methods}

Beyond research and theoretical understanding of the transport corridors and their role in regional development, the continuation of the study and research topic focused toward concrete analyzing of an Albanian case study. Below is the way which is followed for the data collection and which methodology is adapted to attend for it.

The social impact analyses were focused on stakeholder's analyses while the economic impact analysis will be oriented towards analyzing the analysis of the annual report. 1) The first is stakeholder analysis; 2) The second Annual Reports Analysis.

Stakeholder Analysis considers as an important technique for stakeholder identification and analyzing their needs. In this case it will use to identify all key (primary and secondary) stakeholders who have an interest in the issues with which the project is concerned. In this case, which is important for Albania and Kosovo too, generate their activity a series of individuals, for whom rise two questions; who has the power and who has the interest?

\begin{tabular}{|l|l|l|}
\hline No. & Power & Interest \\
\hline 1. & Investors & Taxi driver \\
\hline 2. & Citizens (Type1) & Bus driver \\
\hline 3. & Transport companies & Shop service \\
\hline 4. & Citizens (Type2) & Individuals (key in flows) \\
\hline 5. & Farmers & \\
\hline
\end{tabular}

Citizens (Type1), those who live near access points 
Citizens (Type2), those who live far, or on the other side of the area.

For the two questions raised above the table lists a list of those individuals or groups who have the interest or the power to use this corridor. Each of them has individual intentions that are expressed based on the interest they have to move from one point to another, from origin to destination. In the case of those who have the power, (investors, citizens, transport companies, farmers):

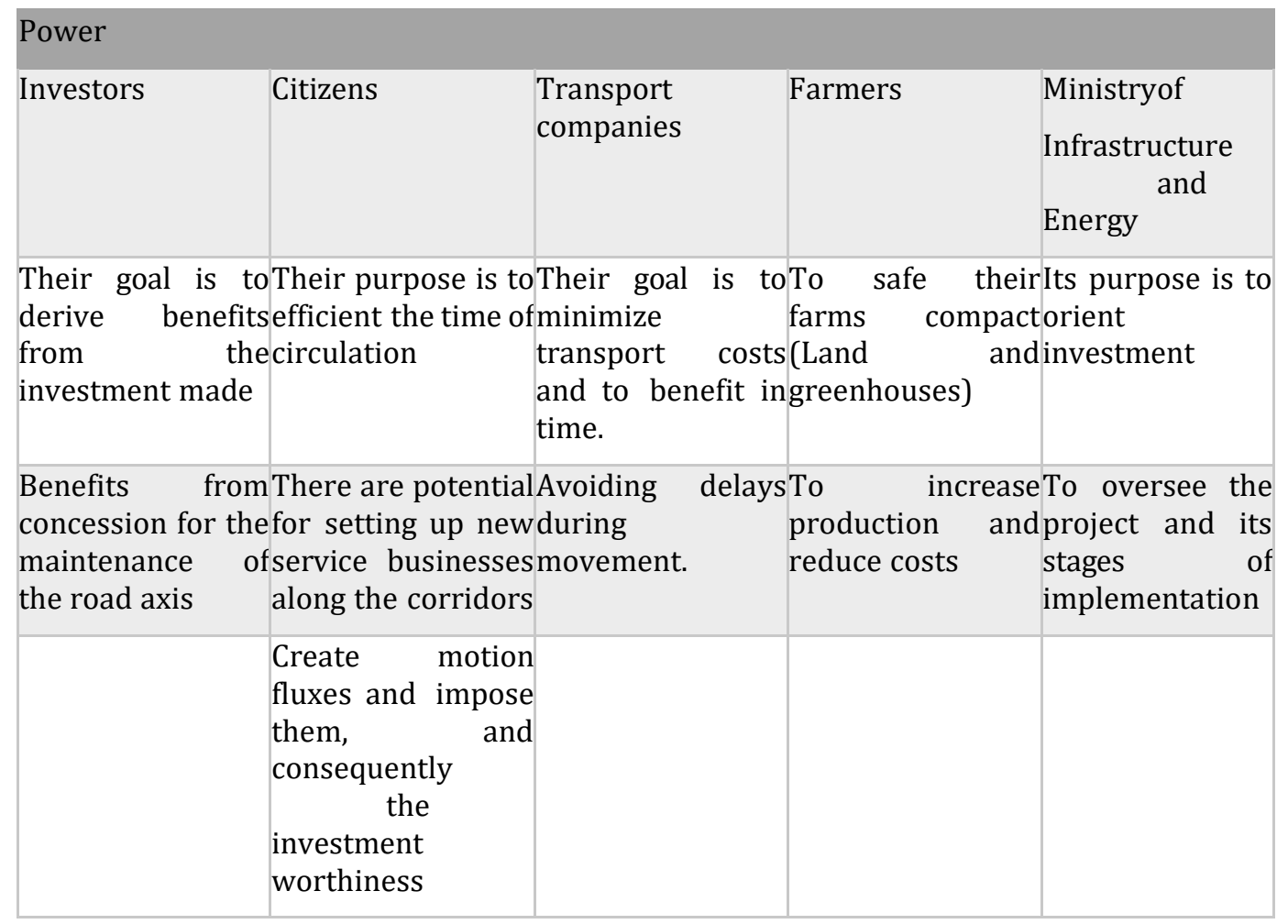

Source: the author.

In the case of those who have interest (Taxi driver, Bus driver, Shop service, Individuals):

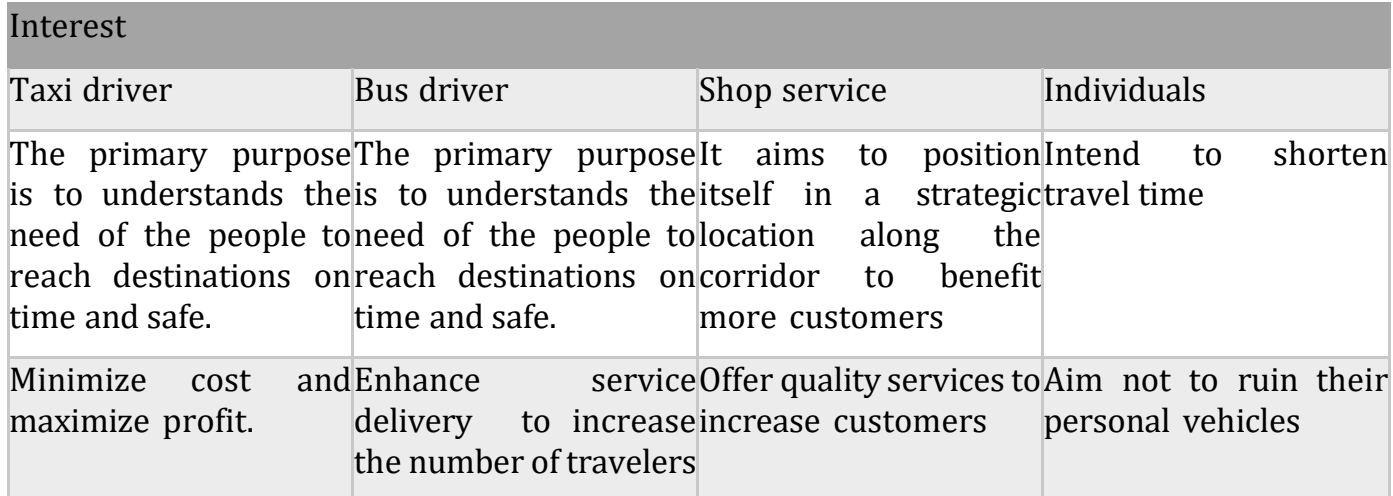


To achieve significantthere should be low taxAims to have low They should be safe gains and increase therates for roadcompetition toduring the journey frequency of the road. frequency. maximize profit

Access different points (cities) along the voyage, providing access and exit along the corridor

Source: the author.

POWER

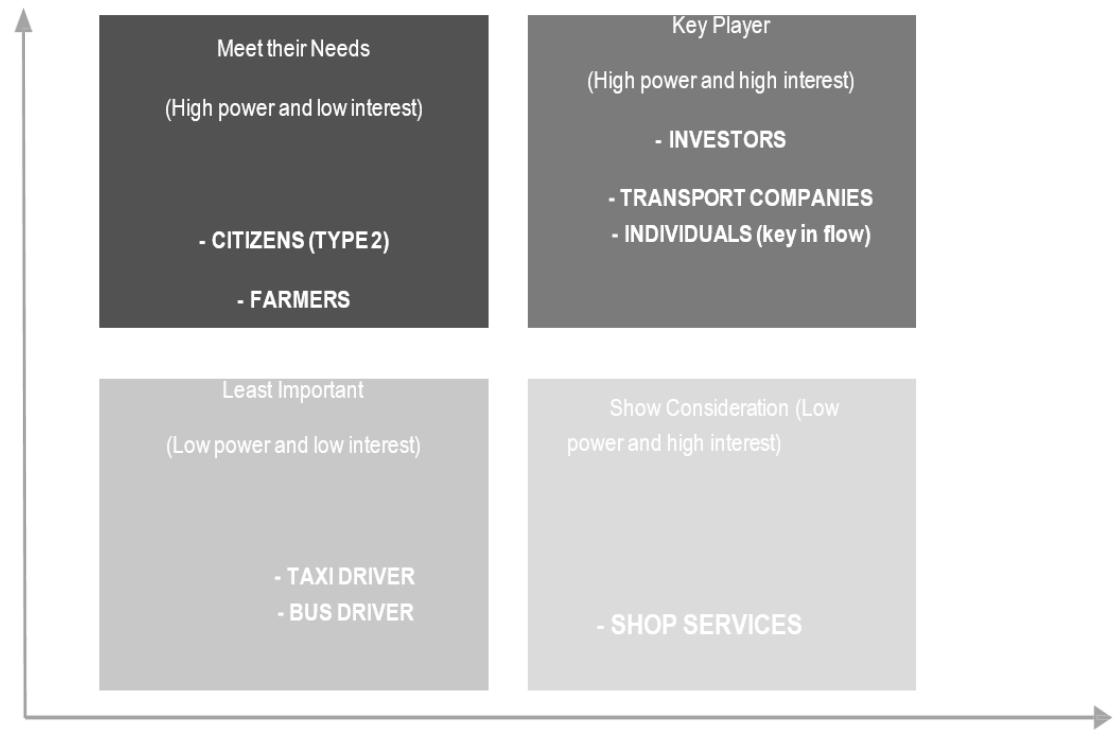

Source: the author.

\section{INTEREST}

In the above chart are positioned according to interest and their stakeholder power which, depending on the level expressed, have taken the positioning. The methodology used is based on how stakeholder analysis is built considering those who have more relevance and influence in this analysis.

To better understand the level of engagement and satisfaction for the project, has been used the scale rank, which has 5 levels of stakeholder that have been analyzed above.

The five levels that are taken into consideration are explained below.

\begin{tabular}{|l|l|l|l|l|l|}
\hline Stakeholder & Unaware & Resistant & Neutral & Supportive & Leading \\
\hline Investors & & & & $\mid$ & \\
\hline $\begin{array}{l}\text { Citizens } \\
\text { (Type1) }\end{array}$ & & & & & \\
\hline
\end{tabular}




\begin{tabular}{|l|l|l|l|l|l|}
\hline $\begin{array}{l}\text { Transport } \\
\text { companies }\end{array}$ & & & & & \\
\hline $\begin{array}{l}\text { Citizens } \\
\text { (Type2) }\end{array}$ & & & & & \\
\hline Taxi driver & & & & & \\
\hline Bus driver & & & & I & \\
\hline Shop service & & & & I & \\
\hline $\begin{array}{l}\text { Individuals } \\
\text { (key in flows) }\end{array}$ & & & & I & \\
\hline Farmers & & & & & \\
\hline
\end{tabular}

\section{Source: the author.}

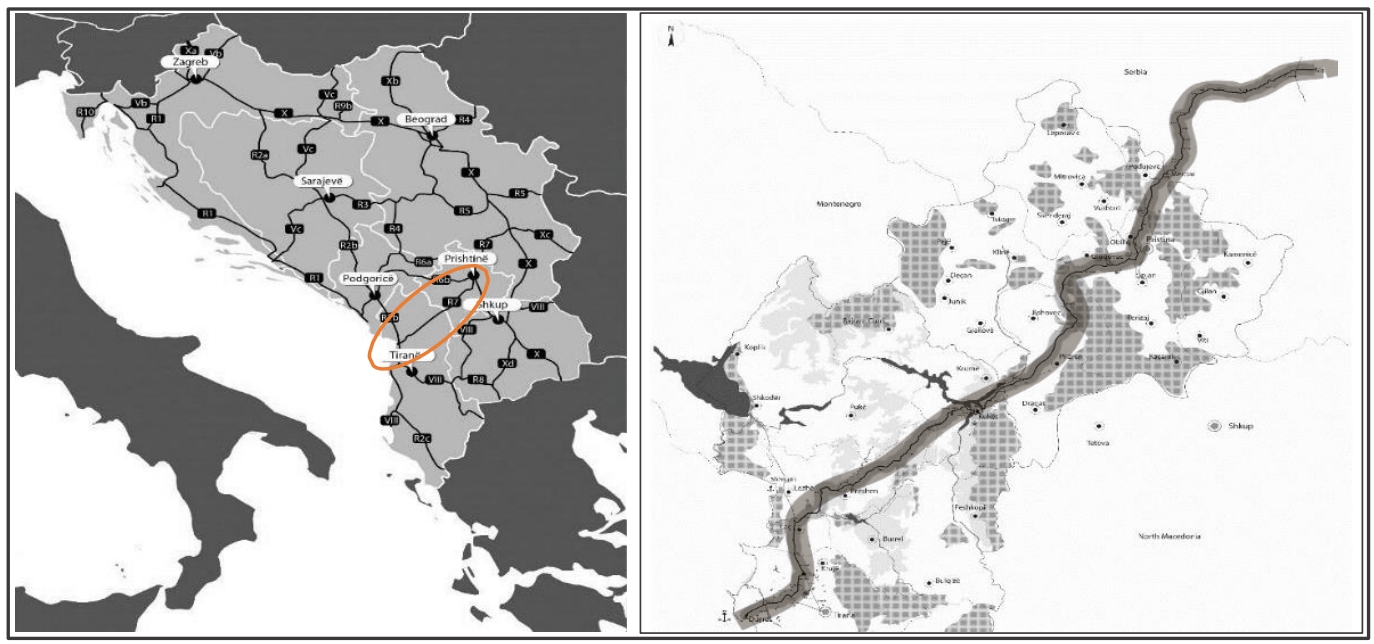

Fig.1 Route 7 part of Corridor X, Durres-Nish.

Fig. 2 "The Road of the Nation", (Route 7) Durres-Nish. Source: the author. Source: graphic edit the author.

\section{Annual Reports Analysis}

The four-lane highway became the largest infrastructure project in Albania. Its initial cost was estimated at about $€ 600$ million, but then it came close to $€ 1$ billion, though it never came to a final figure of its full cost up to the current stage.

Often times, the economics specialists, starting from the huge cost change, with almost $80 \%$ of the initial cost, which has often sparked little debate in Albania, have led to the question of whether this route has been economically rentable, which means if the economic benefits are higher than the costs of building this road.

In October 2003, Albania and Kosovo liberalized a considerable trade between them, to reach in 2007 with CEFTA entry into full liberalization of bilateral trade. 
In 2009, the value of import / export amounted to about 10 million euros, a figure similar to the whole 2003-2006 period (10.4 million euro) (INSTAT 2015). The Albanian Institute of Statistics shows that during the period 2010-2014, exports were those who suffered significant fluctuation, but they have been drastically increasing compared to 2009 levels. There was a trend up until 2012, which went down in 2013 and marked an increase in 2014. Thus during 2014, they accounted for $7.3 \%$ of exports from $6.2 \%$ in 2010 . Albanian exports to Kosovo during this period were mainly concentrated in the "Minerals, fuels, electricity" and "Construction materials and metals" groups INSTAT.

According to INSTAT data, in 2015, the volume of trade exchange between the two countries amounted to ALL 26 billion, marking an increase of almost three times, compared to the level of 2009 and over 7 times from 2005 INSTAT.

In 2015, Kosovo became the second most important Albanian export destination for the first time. They reached almost ALL 21 billion or about $11.4 \%$ more than in 2014. In 2015, exports to Kosovo accounted for $8.6 \%$ of the total, from $7.3 \%$ in 2014 and $4.7 \%$ in 2007 before the Durres Kukës road (K.Prifti 2018).

The most exported product from Albania to Kosovo in 2015 was cast iron and steel with about ALL 5.4 billion ( $4 \%$ annual growth) followed by fuels and minerals, with about ALL 5 billion, which saw an annual increase of 22\% (K.Prifti 2018).

Excessive growth, albeit from a small base, in the same period marked the export of agricultural products. Vegetables sales in Kosovo increased by $45 \%$, reaching 750 million ALL. Even the exported fruits were 50\% higher than the previous year, to reach nearly 600 million ALL.

Other businesses that have seen increased activity with Kosovo are also the ore processors and furniture makers. While cement is one of the products that failed to find the neighboring market in 2015 (K.Prifti 2018).

In addition to the tourism sector, "Nation's Road", was given the opportunity for Kosovo Albanians to have a tourist destination that offered everything from the point of view of natural resources, otherwise called "patriotic tourism" and compared to "SanTropez" tourism for compatriots. INSTAT data shows that inflows of foreign allowances across the land border (where Morina's inflows accounted for more than 50\% of the total) marked a significant increase shortly after 2008, fivefold by 2015 .

In 2010, the number of foreign visitors to Albania was estimated at about 3.5 million, of which about 1.7 million were citizens of Kosovo. In one year in Albania there are about 1.5-1.8 million citizens from Kosovo, $70 \%$ of whom come during the period June-August. According to statistics,

a citizen from Kosovo stays in Albania on average 3.8 days and 83\% of them stay at the hotel. The average daily cost per person of a citizen from Kosovo amounts to 55 EUR, (INSTAT 2015). 


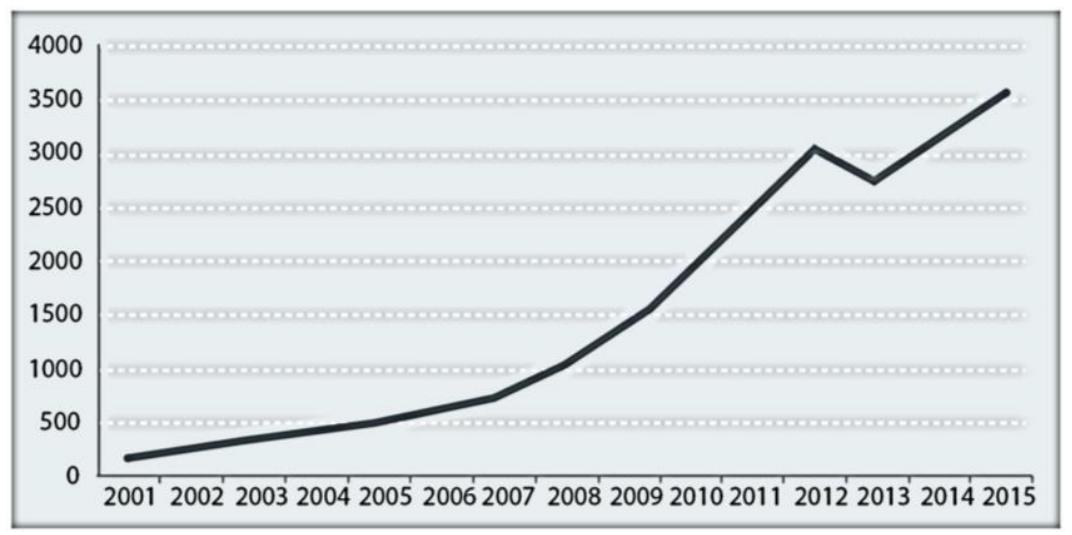

Graphic 1. Entries of foreign nationals through the land border in years (thousand). Source: INSTAT Albania.

During 2009, the tourism industry estimated a value that was about $29 \%$ higher than that of export of goods and services. The shortened travel distance (in 2.5 hours) made coastal areas more accessible and at a lower cost. From the calculation of this data using INSTAT statistics, it turns out that the annual economic benefit of Albania only from the development of tourism sector with Kosovo that has brought the construction of this highway is as follows:

\begin{tabular}{|c|c|c|}
\hline No. tourists & Average daily spending Day of stay & Benefit \\
\hline 1.7 million (KS) & 3.8 davs & 355.300000 FUR \\
\hline
\end{tabular}

\section{Conclusions}

At the end, this research concludes that some of the obtained results are part of a subjective assessment made by the author and his reasoning on the case and the data that has been possible to gather. At the end of this assessment of this corridor, first in social terms, it is more positive as it has affected the speed of movement of residents and their access to certain services. The economic impact of this investment is huge but in this case the study is try to be more oriented in specific sectors where it had more impact.

Another positive impact has been the investment in this road has also been and the "employment".

In the table below are identifying some evidence and economic data, which are classifying as the positive and negative effects that the " the Road of Nation" has had at regional and national levels.

\begin{tabular}{|l|l|l|}
\hline No. & Positive Impact & Negative Impact \\
\hline 1. & $\begin{array}{l}\text { Increasing employment in one of the } \\
\text { poorest regions of Albania }\end{array}$ & High project cost \\
\hline 2. & Minimize transport cost & $\begin{array}{l}\text { Interruption of other investments in public } \\
\text { infrastructure during the construction of this } \\
\text { road }\end{array}$ \\
\hline
\end{tabular}




\begin{tabular}{|c|c|c|}
\hline 3. & Reduce of circulation time & Increasing public debt for investment \\
\hline 4. & Creating a common economic space & The impact of policy on project decision making \\
\hline 5. & $\begin{array}{l}\text { Increase in the level of trade between } \\
\text { Albania and Kosovo }\end{array}$ & Low efficiency of the project \\
\hline 6. & Development of the tourism sector & $\begin{array}{l}\text { Political allegations of corruption and } \\
\text { misappropriation of government funds }\end{array}$ \\
\hline 7. & $\begin{array}{l}\text { Development of access from the port of } \\
\text { Durres }\end{array}$ & $\begin{array}{l}\text { Failure to improve logistics for the port of } \\
\text { Durres }\end{array}$ \\
\hline 8. & Increasing the number of tourists & $\begin{array}{l}\text { Non-financing of residents during areas where } \\
\text { the old road was passing }\end{array}$ \\
\hline 9. & $\begin{array}{l}\text { Impact on other sectors (properties, } \\
\text { real estate agencies) }\end{array}$ & \\
\hline 10. & Development of inter-regional links & \\
\hline 11. & $\begin{array}{l}\text { Creating better opportunities for } \\
\text { countries like Kosovo and Serbia to have } \\
\text { quick access to the Adriatic Sea and } \\
\text { beyond. }\end{array}$ & \\
\hline
\end{tabular}

In general, public investments in the road transport infrastructure and not just in the nation's road have two main economic benefits. These benefits consist of, a) increase of interregional access, b) reducing the cost of transport (at regional level and wider). Taking into consideration these benefits, it is expected that transport will affect direct and indirect economic growth (through other factors) as appropriate. In Albania, high spending on public investment over the years has increased productivity and have added accumulation of public capital. Investment on this historic road in general, has a positive social impact for the reason of resident's connection and generation of life in this areas.

\section{Bibliography}

[1] D. Banister and N. Lichfield (1995), Transport and urban development. E \& FN SPON An Imprint of Chapman \& Hall, edited by Alexandrine Press, Oxford.

[2] Dwyer, D.J. (ed) (1990), Southeast Asian Development: Geographical Perspectives, Esses, England: Longman

[3] F. O'Sullivan, The Egnatian Way (Great highway series). Newton Abbot: David \& Charles; Harrisburg: Stackpole Books, 1972. Pp. 264.

[4] FORUM, (2013), Roads to a Common Economic Space Albania - Kosovo. Document Curiaweb, Supported by the Konrad Adenauer Foundation

[5] HOYLE. B. S. (ed) (1973), Transport and development, geographical readings, pg.10, London: Macmillan. Selection, editorial matter and introduction by B.S. HOYLE. 
[6] INSTAT (Instituti i Statistikave), institute of statistics of Albania (2019). K.Prifti, (2018), The economic profitability of the Nation Road.

[7] J.-P. Rodrigue (1996), Transportation Corridors in Pacific Asian Urban Regions, Department of Geography, Centre for Research on Transportation, East Asian Studies Centre, Université de Montréal.

[8] M. Fasolo, La via Egnatia I. Da Apollonia e Dyrrachium and Herakleia Lynkestidos (1976), Roma 2003. Stampa: I.G.E.R. srl, ISTITUTO GRAFICO EDITORiALE ROMANO di Pieraldo Vola \& Figli 